Weronika Krajniak

(Archiwum Uniwersytetu Mikołaja Kopernika w Toruniu)

krajniak@umk.pl

\title{
Rys historyczny Archiwum Uniwersytetu Mikołaja Kopernika w Toruniu
}

Archiwum Uniwersytetu Mikołaja Kopernika w Toruniu w strukturze organizacyjnej uczelni jest ogólnouczelnianą jednostką o zadaniach usługowych, dydaktycznych i naukowych. Wchodzi w skład państwowej sieci archiwalnej i pełni funkcję archiwum zakładowego uprawnionego do posiadania zasobu historycznego ${ }^{1}$. Jako jednostka uczelniana podlega Rektorowi UMK, natomiast nadzór merytoryczny nad jej działalnością sprawuje Archiwum Państwowe w Toruniu ${ }^{2}$. Archiwum działa na podstawie: ustawy z 14 lipca

${ }^{1}$ Art. 22. ust. 1. oraz art. 35. ust. 2. Ustawy o narodowym zasobie archiwalnym $i$ archiwach z dnia 14 lipca 1983 r., Dz.U. nr 38, poz. 173 (z późn. zm.); Archiwum UMK (dalej AUMK), Akta własne, Organizacja jednostek organizacyjnych działalności podstawowej. Archiwum UMK, Zarzadzenie NDAP z dnia 15 marca 1958 r. w sprawie zezwolenia szkołom wyższym na wieczyste przechowywanie akt własnych, sygn. 2002/3; zob. też: H. Duczkowska-Moraczewska, Archiwum Uniwersytetu Mikotaja Kopernika (1948-1980), [w:] Uniwersytet Mikotaja Kopernika 1966-1980, pod red. J. Bełkota, t. 2, Toruń 1992, s. 135; I. Janosz-Biskupowa, Archiwum Uniwersytetu M. Kopernika w Toruniu (1948-1968), „Zeszyty Naukowe Uniwersytetu Mikołaja Kopernika w Toruniu. Nauki Humanistyczno-Społeczne. Historia" 1969, t. 5(36), s. 72-73.

2 Akta Sekretariatu Rektora, Zarządzenia Rektora UMK od 15 V 1974 do 30 IX 1975 r., Zarzadzenie Rektora UMK nr 32 z dnia 15 stycznia 1975 r. w sprawie organizacji i zakresu działania Archiwum Uniwersytetu Mikołaja Kopernika w Toruniu, uregulowało kwestie dotyczące organizacji i zakresu działania Archiwum UMK, nadając mu status pozawydziałowej jednostki organizacyjnej, podlegającej bezpośrednio Rektorowi, sygn. R-35/1. Do tego czasu archiwum występowało jako zakład naukowy. W aktach Sekretariatu Rektora, Zarządzenia Rektora UMK od 15 V 1974 do 30 IX 1975 r. znajdziemy również Zarządzenie Rektora UMK nr 34 z dnia 25 stycznia 1975 r. w sprawie powołania Komisji rektorskiej ds. Archiwum, sygn. R-35/1. Pierwsze jej posiedzenie odbyło się 26 października 1978 r. Komisja działała do $1980 \mathrm{r}$. W tym też roku utworzono Komisję Archiwalną i Biblioteczną, która z racji innych funkcji obu jednostek nie przetrwała. 10 stycznia 1984 r. powołano nową Radę Archiwum UMK, AUMK, Akta własne, Organy Kolegialne. Rada Archiwum. Komisja ds. Archiwum, sygn. 2002/1; H. Duczkowska- 
1983 r. o narodowym zasobie archiwalnym i archiwach, statutu UMK, regulaminu organizacyjnego archiwum oraz przepisów kancelaryjno-archiwalnych $^{3}$. Niniejszy artykuł porządkuje i uzupełnia dotychczasowej informacje, podane we wcześniejszej literaturze dotyczącej archiwum. Jest jednym z niewielu tekstów, który został opatrzony aparatem naukowym, obejmującym nie tylko dostępne publikacje, ale przede wszystkim materiał źródłowy.

$* * *$

Archiwum uniwersyteckie zostało powołane uchwałą Senatu UMK z 16 września $1948 \mathrm{r}^{4}$ Organizacje powierzono historykowi, prof. Bronisławowi Włodarskiemu ${ }^{5}$, który jednocześnie otrzymał upoważnienie do swobodnego doboru personelu spośród pracowników naukowych Instytutu Historycznego Wydziału Humanistycznego UMK. W pracy nad kształtowaniem zasobu archiwalnego prof. Włodarskiego wspierał asystent, ówczesny magister Tadeusz Grudziński, późniejszy profesor $\mathrm{UMK}^{6}$. Został zatrudniony 1 października 1949 r., ale już 1 września 1951 r. przeszedł do Katedry Historii Polski Średniowiecznej Wydziału Humanistycznego UMK. W kwietniu 1951 r. prof. Włodarski zrezygnował z kierowania jednostką. Przypuszczalnie obowiązki kierownika od kwietnia do października pełnił doc. Leonid Żytkowicz? Pierwszym miejscem przeznaczonym na archiwum był niewielki pokój nr 26 na II piętrze w Collegium Maius przy ul. Fosa Staromiejska $3^{8}$. W pierwszych latach jego istnienia zasób ograniczał się jedynie do wycinków prasowych

\footnotetext{
-Moraczewska, B. Kierzkowska, Sześćdziesiąt lat Archiwum Uniwersytetu Mikołaja Kopernika w Toruniu, [w:] Jubileusz 60-lecia Archiwum Uniwersytetu Mikołaja Kopernika w Toruniu. Materiaty $z$ konferencji, pod red. K. Stryjkowskiego, Poznań 2009, s. 17 zob. też Przepisy kancelaryjno-archiwalne, oprac. H. Duczkowska-Moraczewska, H. Robótka, Toruń 2004, s. 105.

${ }^{3}$ Obwieszczenie nr 4 Rektora UMK z dnia 21 czerwca 2017 r. w sprawie tekstu jednolitego uchwały Senatu UMK nr 135 z dnia 22 października 2013 r. w sprawie uchwalenia Statutu Uniwersytetu Mikołaja Kopernika w Toruniu, https://www.umk.pl/uczelnia/dokumenty/ statut/Statut_UMK.pdf (dostęp 3 listopada 2017); Zarządzenie Rektora UMK nr 173 z dnia 7 grudnia 2009 r. w sprawie regulaminu organizacyjnego Uniwersytetu Mikołaja Kopernika w Toruniu, „Biuletyn Prawny UMK”, nr 10 z 16 grudnia 2009 r.; Przepisy kancelaryjno-archiwalne; Regulamin organizacyjny Archiwum UMK z 1992 r.; Ustawa z dnia 14 lipca 1983 r. o narodowym zasobie archiwalnym.

${ }^{4}$ AUMK, Akta Sekretariatu Rektora, Protokoły posiedzeń Senatu UMK z lat 1946-1950, sygn. $30 / 1 b$.

${ }^{5}$ Zob. W. Krajniak, Włodarski Bronistaw Adolf(1895-1974), [w:] Toruński Stownik Biograficzny (dalej TSB), t. 7, Torun 2014, s. 251-255.

${ }^{6}$ H. Duczkowska-Moraczewska, B. Kierzkowska, dz. cyt., s. 16-17.

7 Patrz przypis nr 57.

${ }^{8}$ H. Duczkowska-Moraczewska, dz. cyt., s. 139; I. Janosz-Biskupowa, dz. cyt., s. 75.
} 
dotyczących działalności uniwersytetu ${ }^{9}$. Pierwsze akta przejęto 23 stycznia 1951 r. z Wydziału Humanistycznego ${ }^{10}$. Nieco później, 28 marca tego roku, akta przekazał Sekretariat Rektora ${ }^{11}$, a także Towarzystwo Przyjaciół Młodzieży Szkół Wyższych (31 marca) oraz Dział Nauczania (11 lipca) ${ }^{12}$.

W następnych latach kierownikami archiwum byli kolejno: doc. Żytkowicz $^{13}$, zatrudniony jako pracownik kontraktowy Wydziału Humanistycznego, ale oddelegowany na kierownika archiwum w wymiarze 36 godzin tygodniowo, oraz dr Józef Mossakowski, który do pomocy, w ramach godzin zleconych, miał starszego pedla Kazimierza Nowickiego ${ }^{14}$. W czasie, gdy kierownikiem był doc. Żytkowicz, 22 września 1952 r. archiwum przeniesiono do nieco większego pomieszczenia nr 55 na III piętrze tego samego budynku. Pokój ten miał $100 \mathrm{~m}^{2} \mathrm{i}$ był wyposażony w pięć zamykanych szaf ${ }^{15}$. Ważnym momentem dla archiwum był 8 października 1952 r. Wtedy Ministerstwo Szkolnictwa Wyższego wydało zarządzenie w sprawie tworzenia i przechowywania akt wytworzonych przez uczelnie ${ }^{16}$. Instrukcja wprowadzała przede wszystkim podział akt na kategorie oraz obowiązek przekazywania ich do archiwum uczelnianego. Rozdział IV, par. 2. tego zarządzenia przewidywał istnienie archiwum szkoły, wchodzące w skład sekretariatu uczelni, ale par. 3. zezwalał na istnienie archiwum jako zakładu naukowego. Tak też traktowane było archiwum przez władze uniwersytetu ${ }^{17}$.

18 marca 1953 r. mgr Janina Baluszewska z oddziału Wojewódzkiego Archiwum Państwowego (WAP) w Toruniu (obecnie Archiwum Państwowe) przeprowadziła pierwszą wizytację. W protokole odnotowała, że na UMK

${ }^{9}$ I. Janosz-Biskupowa, dz. cyt. s. 77.

10 Tamże, s. 77.

11 Tamże, s. 77.

${ }^{12}$ H. Duczkowska-Moraczewska, B. Kierzkowska, dz. cyt., s. 17; I. Janosz-Biskupowa, dz. cyt., s. 77.

${ }^{13}$ Leonid Żytkowicz zatrudniony był jako pracownik kontraktowy Wydziału Humanistycznego, ale oddelegowany na kierownika Archiwum UMK w wymiarze 36 godzin tygodniowo. H. Duczkowska-Moraczewska, B. Kierzkowska, dz. cyt., s. 17; zob. też A. Piątkowski, Żytkowicz Leonid (1909/10-1991), [w:] TSB, t. 2, Toruń 2000, s. 280-282.

${ }^{14}$ I. Janosz-Biskupowa, dz. cyt., s. 75; w protokole wizytacyjnym składnicy akt Uniwersytetu Mikołaja Kopernika w Toruniu, nr 221/192/129, K. Nowicki występuje na stanowisku pomocnika, Akta własne Archiwum UMK, sygn. 2002/11; Zob. też J. Serczyk, Mossakowski Józef (1897-1972), [w:] TSB, t. 1, Torun 1998, s. 181.

15 AUMK, Akta własne, Kontrola zewnętrzna [Archiwum Państwowe], Protokół wizytacji składnicy akt Uniwersytetu Mikołaja Kopernika w Toruniu, L. 1625/53, (odpis), sygn. 2002/11.

16 AUMK, Akta własne, Organizacja jednostek organizacyjnych działalności podstawowej. Archiwum UMK, sygn. 2002/3, Zarzadzenia nr 39 Ministra Szkolnictwa Wyższego z dnia 8 października 1952 r. w sprawie wprowadzenia instrukcji kancelaryjnych w szkotach wyższych; zob. też I. Janosz-Biskupowa, dz. cyt., s. 71-72.

${ }^{17}$ H. Duczkowska-Moraczewska, B. Kierzkowska, dz. cyt., s. 18; I. Janosz-Biskupowa, dz. cyt., s. 72 . 
działają dwie składnice akt. Jedna, licząca 17 mb., 80 paczek, 29 segregatorów i 3 wiązki, którą opiekował się ówczesny kierownik archiwum, oraz druga, składająca się z 4 mb., 235 segregatorów, 200 wiązek i 4 teczek, którą opiekowała się Felicja Litwin ${ }^{18}$. Akta te pochodziły z Kwestury UMK i z uwagi na to, że dotyczyły majątków uniwersyteckich, przechowywane były w skarbcu Collegium Minus (tzw. „Harmonijce”) przy ul. Fosa Staromiejska 1a. Akta z obu składnic pochodziły z lat 1945-1951 ${ }^{19}$.

Za kierownictwa dr. Mossakowskiego $\mathrm{w}$ protokole powizytacyjnym z 28 października 1955 r. mgr Karola Ciesielska z oddziału WAP w Toruniu odnotowała zasób liczący $40 \mathrm{mb}$. akt, w tym akta zlikwidowanego w $1954 \mathrm{r}$. Studium Przygotowawczego UMK (30 mb.) i akta Rektoratu (5 mb. $)^{20}$. Powiększający się zasób spowodował, iż we wrześniu 1955 r. uzyskano kolejne pomieszczenie w piwnicy budynku Collegium Maius, o powierzchni $54 \mathrm{~m}^{2}$. Było to wąskie miejsce, dlatego też dla wykorzystania przestrzeni postawiono w nim regały do sufitu. Pomieszczenie to nie było dobrym lokum dla archiwum, gdyż znajdował się tam węzeł centralnego ogrzewania, który kilkakrotnie był przebudowywany, co wiązało się z dezorganizacją pracy instytucji, a także zniszczeniem akt ${ }^{21}$. W $1963 \mathrm{r}$. odbyła się kolejna wizytacja pracownika WAP w Toruniu. Ówczesna dr Irena Janosz-Biskupowa zaznaczyła, że zasób z lat 1945-1962 wynosił 287 mb., w tym 162 mb. akt zgromadzonych w Kwesturze UMK ${ }^{22}$.

Szczególne zasługi dla rozwoju jednostki należą się właśnie doc. Irenie Janosz-Biskupowej, której w 1966 r. powierzono obowiązki kierownika ${ }^{23}$. To z jej inicjatywy w tym samym roku odbyła się w Toruniu ogólnopolska narada archiwistów uniwersyteckich z udziałem przedstawicieli Naczelnej Dyrekcji Archiwów Państwowych, w trakcie której dyskutowano nad opracowanym projektem ramowym statutu archiwum szkoły wyższej ${ }^{24}$. Efektem narady było

18 AUMK, Akta własne, Kontrola zewnętrzna [Archiwum Państwowe], sygn. 2002/11, Protokół wizytacji składnicy akt Uniwersytetu Mikołaja Kopernika w Toruniu, L. 1625/53, (odpis); H. Duczkowska-Moraczewska, B. Kierzkowska, dz. cyt., s. 17-18.

19 AUMK, Akta własne, Kontrola zewnętrzna [Archiwum Państwowe], sygn. 2002/11; H. Duczkowska-Moraczewska, B. Kierzkowska, dz. cyt., s. 17-18. W latach 30.-40. XX w. w budynku mieściła się Komunalna Kasa Oszczędności Województwa Pomorskiego.

20 AUMK, Akta własne, Kontrola zewnętrzna [Archiwum Państwowe], sygn. 2002/11, Protokół wizytacji składnicy akt Uniwersytetu Mikołaja Kopernika w Toruniu, nr 221/192/129; H. Duczkowska-Moraczewska, B. Kierzkowska, dz. cyt., s. 19.

${ }^{21}$ I. Janosz-Biskupowa, dz. cyt., s. 75-76.

22 AUMK, Akta własne, Kontrola zewnętrzna [Archiwum Państwowe], sygn. 2002/11, Protokół wizytacji składnicy akt Uniwersytetu Mikołaja Kopernika w Toruniu, z dnia 28 maja i 6 czerwca 1963 r.; H. Duczkowska-Moraczewska, B. Kierzkowska, dz. cyt., s. 19.

${ }^{23}$ H. Duczkowska-Moraczewska, B. Kierzkowska, dz. cyt., s. 20-21, 24; H. Duczkowska-Moraczewska, dz. cyt., s. 135.

${ }^{24}$ Ustalenie statutu archiwów uczelnianych było niezmiernie ważne, gdyż do tegoż dnia sytuacja prawna archiwów szkół wyższych była nieokreślona, powodowało to dowolność w pro- 
przyjęcie w tym samym roku do zasobu Archiwum UMK pierwszej spuścizny po prof. Jadwidze Lechickiej ${ }^{25}$. Jednocześnie kierownik archiwum zapoczątkowała także gromadzenie fotografii oraz nagrań dotyczących wydarzeń $\mathrm{w}$ uniwersytecie oraz akt stowarzyszeń działających w UMK ${ }^{26}$. Przez szereg lat obsada Archiwum UMK była jednoosobowa. W pracach pomagali jedynie asystenci z Katedry Archiwistyki i Nauk Pomocniczych Historii UMK oraz studenci zatrudniani $w$ ramach prac zleconych ${ }^{27}$. Doc. Biskupowej pomagali ówcześni magistrowie (późniejsi profesorowie i pracownicy UMK): Bohdan Ryszewski przez 4 godziny tygodniowo (od 15 marca $1966 \mathrm{r}$.) ) $^{28}$ oraz Jan Pakulski (od października 1966 r.) ${ }^{29}$. W protokole powizytacyjnym z 13 grudnia 1972 r. mgr Teresa Koba-Ryszewska (pracownica WAP) odnotowała, iż zasób archiwum składa się z dokumentacji aktowej z lat 1945-1970 (akta wydziałowe, komórek i jednostek administracyjnych oraz inne zespoły obce), a także spuścizn (dr. Adama Dygdały, prof. Jadwigi Lechickiej i prof. Tadeusza Czeżowskiego). Łączny zasób archiwum liczył ok. 50000 j.a. w tym, akt kat. A ok. 25000 j.a. ${ }^{30}$ Prawdopodobnie za kierownictwa doc. Janosz-Biskupowej powstała biblioteka podręczna archiwum. Doc. Janosz-Biskupowa, z pewnością na wzór biblioteki podręcznej archiwów państwowych, postanowiła stworzyć księgozbiór w Archiwum Uniwersyteckim. Akta z 1966 r. odnotowują pierwsze informacje z prośbą o uzupełnienie biblioteki podręcznej o pozycje na temat archiwów, ich kancelarii, ale także książek i informatorów dotyczących Uniwersytetu Mikołaja Kopernika ${ }^{31}$. 1 października 1969 r. do

wadzeniu archiwów. Niestety, Ministerstwo Szkolnictwa Wyższego nie przejęło się projektem, mimo ponagleń ze strony innych uniwersytetów i NDAP. Dlatego ówczesny rektor UMK prof. Witold Łukaszewicz polecił stosować ustalenia konferencji, AUMK, Akta własne, Organizacja jednostek organizacyjnych działalności podstawowej. Archiwum UMK, sygn. 2002/3; zob. też: I. Janosz-Biskupowa, dz. cyt., s. 82-83; tejże, Spotkanie archiwistów uniwersyteckich, zorganizowane przez sekcje archiwalna Polskiego Towarzystwa Historycznego w Toruniu, „Archeion” 1967, t. 47, s. 205-206; J. Pakulski, Pierwsza ogólnopolska konferencja archiwistów uniwersyteckich, "Archiwista” 1967, nr 2, s. 18-22.

${ }^{25}$ I. Janosz-Biskupowa, Archiwum Uniwersytetu M. Kopernika w Toruniu, s. 79.

26 Tamże, s. 79.

27 Tamże, s. 71.

28 AUMK, Akta własne, Plany roczne i sprawozdania z ich wykonania. Archiwum UMK, Sprawozdanie z dnia 28 czerwca 1966 r. z prac wykonanych w okresie od 2 I do 30 VI 1966 r. oraz projekt dalszych prac i organizacji Archiwum UMK, sygn. 2002/6; Kontrola zewnętrzna [Archiwum Państwowe], Protokół powizytacyjny składnicy akt z 29 września 1966 r., sygn. 2002/11.

${ }^{29}$ I. Janosz-Biskupowa, Archiwum Uniwersytetu M. Kopernika w Toruniu, s. 75.

30 AUMK, Akta własne, Kontrola zewnętrzna [Archiwum Państwowe], sygn. 2002/11.

31 AUMK, Akta własne, Gromadzenie zbiorów bibliotecznych. Zakup zbiorów na rynku krajowym [i inny sposób pozyskiwania: dary], sygn. 2001/46. Więcej o bibliotece zob. W. Krajniak, Biblioteka podręczna Archiwum Uniwersytetu Mikołaja Kopernika w Toruniu, „Folia Toruniensia" 2014, t. 14, s. 97-99. 
pracy w archiwum oddelegowano mgr Henrykę Duczkowską-Moraczewską ${ }^{32}$. Kolejna zmiana siedziby nastąpiła w styczniu $1970 \mathrm{r} .{ }^{33}$ Wtedy archiwum otrzymało cztery pomieszczenia o łącznej powierzchni $110 \mathrm{~m}^{2}$, w lewym skrzydle wspomnianego już Collegium Maius ${ }^{34}$. Lokal ten traktowano jako zastępczy, gdyż docelowo archiwum miało znajdować się w nowym gmachu Rektoratu, w miasteczku uniwersyteckim na Bielanach. Przeniesienie do nowego budynku nastąpiło w październiku 1972 r. ${ }^{35}$ Niestety, archiwum na krótko zagościło w gmachu administracji, w której otrzymało pokoje 109-110 na I piętrze, o łącznej kubaturze $68,9 \mathrm{~m}^{2}$, oraz pomieszczenie $\mathrm{nr} 5$ o powierzchni $103,10 \mathrm{~m}^{2}$, znajdujące się $\mathrm{w}$ piwnicy budynku ${ }^{36}$. Umiejscowienie magazynów w piwnicy, gdzie przechodziły rury ciepłownicze, znów nie było trafnym wyborem władz. W latach 1972-1975 wielokrotne dochodziło do zalania akt ${ }^{37}$. W lipcu 1975 r. archiwum otrzymało część budynku po Bibliotece Uniwersyteckiej przy ul. Chopina $12 / 18^{38}$. Pomieszczenia spełniały wszelkie wymogi magazynowe, gdyż był to budynek przedwojenny, wzniesiony z myślą o muzeum lub bibliotece ${ }^{39}$. Archiwum ulokowano w zachodnim skrzydle gmachu (od strony ul. Moniuszki). Pozostałą część budynku zajął Wydział Matematyki Fizyki i Chemii. Na potrzeby archiwum przeznaczono kondygnacje III, IV i V oraz pomieszczenia nr 408, 411-412. Łączna powierzchnia, jaką zajmowało archiwum ${ }^{40}$, wynosiła $441 \mathrm{~m}^{2}$. Zasób archiwum we wrześniu 1976 r. liczył 52687 j.a. ${ }^{41} \mathrm{~W}$ tym samym roku nowym kierownikiem została wieloletnia pra-

32 AUMK, Akta własne, Plany roczne i sprawozdania z ich wykonania. Archiwum UMK, Sprawozdanie z dnia 1 września 1976 r. z działalności Archiwum Uniwersytetu Mikołaja Kopernika za okresu od 2 I 1966 do 1 IX 1976 r., sygn. 2002/6; Kontrola zewnętrzna [Archiwum Państwowe], Protokół powizytacyjny 419-37/224, z dnia 13 XII 1972 r., sygn. 2002/11.

33 AUMK, Akta własne, Plany roczne i sprawozdania z ich wykonania. Archiwum UMK, sygn. 2002/6, w sprawozdaniu z dnia 1 września 1976 r. z działalności Archiwum Uniwersytetu Mikołaja Kopernika w Toruniu za okres od 2 I do 1 IX 1976 r. widnieje informacja o otrzymaniu nowego lokalu w styczniu 1970 r. Por.: H. Duczkowska-Moraczewska, B. Kierzkowska, dz. cyt., s. 17, 19, 22; I. Janosz-Biskupowa, Archiwum Uniwersytetu M. Kopernika w Toruniu, s. 76.

${ }^{34}$ H. Duczkowska-Moraczewska, B. Kierzkowska, dz. cyt., s. 17, 19, 22; I. Janosz-Biskupowa, Archiwum Uniwersytetu M. Kopernika w Toruniu, s. 76.

${ }^{35}$ H. Duczkowska-Moraczewska, B. Kierzkowska, dz. cyt., s. 22-23.

${ }^{36}$ AUMK, Akta własne, Przydział i najem lokali na potrzeby Uczelni [Archiwum UMK], t. 1, sygn. 2001/27.

${ }^{37}$ AUMK, Akta własne, Eksploatacja nieruchomości [m.in. sprawy dot. zalań], sygn. $2001 / 29$

38 AUMK, Akta własne, Organizacja UMK, sygn. 2002/2.

${ }^{39}$ H. Duczkowska-Moraczewska, B. Kierzkowska, dz. cyt., s. 23.

${ }^{40}$ AUMK, Akta własne, Organizacja UMK, sygn. 2002/2.

${ }^{41}$ AUMK, Akta własne, Plany roczne i sprawozdania z ich wykonania. Archiwum UMK, Sprawozdanie z dnia 1 września 1976 r. z działalności Archiwum Uniwersytetu Mikołaja Kopernika za okresu od 2 I 1966 do 1 IX 1976 r., sygn. 2002/6. 
cownica archiwum, ówczesna mgr Duczkowska-Moraczewska ${ }^{42}$ i pełniła tę funkcję do końca $2010 \mathrm{r}$.

W roku 1980 zasób archiwum wzrósł do nieco ponad 60000 j.a., z lat 19451979. W tym też roku wybrakowano ok. $40 \mathrm{mb}$. akt. Ponadto nadal istniała składnica w Kwesturze UMK, gdzie zgromadzono ok. 180 mb. akt. Oddzielną składnicę utworzono także w Rolniczym Zakładzie Doświadczalnym ${ }^{43}$.

W protokole kontroli z 21 grudnia 1987 r. pierwszy raz wspomniano o fotogramach i taśmach magnetofonowych ${ }^{44}$.

Mgr Bożena Staczewska z AP w Toruniu w protokole pokontrolnym z dnia 6 października $1995 \mathrm{r}$. szczegółowo wymieniła zasób archiwum, na który składały się m.in.: akta ogólne z poszczególnych komórek organizacyjnych z lat 1945-1995, ok. 25000 j.a.; akta studenckie $z$ lat 1945-1995 (ok. 75000 j.a.); spuścizny z lat 1945-1995 (26 przejęć); nagrania audio (177 j.a.) i wideo (20 j.a.) z lat 1970-1995; wycinki prasowe $z$ lat 1945-1995; materiały ulotne (ok. 1500 j.a.) oraz pozytywy i negatywy z lat 1945-1995 (ok. 3500 j.a.). Ponadto wymieniono zespoły zamknięte oraz depozyty ${ }^{45}$.

Na przełomie lat 1996/1997 archiwum kolejny raz przeniesiono do nowego budynku na Bielanach, zlokalizowanego pomiędzy Wydziałem Nauk Ekonomicznych i Zarządzania oraz Biblioteką Uniwersytecką przy ul. Gagarina 13a, zyskując trzy magazyny archiwalne o powierzchni $421 \mathrm{~m}^{2} \mathrm{i}$ pomieszczenia biurowe na parterze. Do jednego z nowych magazynów, w którym ulokowano akta studenckie, udało się pozyskać pierwsze regały kompaktowe; kolejną partię zakupiono w grudniu 1999 r. ${ }^{46}$ Wylanie wód gruntowych w 1997 r. oraz zalanie magazynów w 2001 i 2004 r. spowodowało konieczność zamontowania wysokich progów zatrzymujących wodę $e^{47}$.

8 października 2004 r. nastąpiła fuzja Uniwersytetu Mikołaja Kopernika z Akademią Medyczną w Bydgoszczy ${ }^{48}$. Utworzono w tym czasie Collegium $2002 / 4$

42 AUMK, Akta własne, Protokoły zmian na stanowiskach w Archiwum UMK, sygn.

43 AUMK, Akta własne, Kontrola zewnętrzna [Archiwum Państwowe], Protokół powizytacyjny składnicy akt 419-53/224, z dnia 29 IV 1980 r., sygn. 2002/11.

44 AUMK, Akta własne, Kontrola zewnętrzna [Archiwum Państwowe], Protokół kontroli składnicy akt 419-59/224, z dnia 21 XII 1987 r., sygn. 2002/11. Por. przypis 26.

45 AUMK, Akta własne, Kontrola zewnętrzna [Archiwum Państwowe], Protokół kontroli archiwum zakładowego z dnia 6 X 1995 r., sygn. 2002/11.

${ }^{46}$ AUMK, Akta własne, Organy Kolegialne. Rada Archiwum. Komisja ds. Archiwum, sygn. 2002/1; Księga inwentarzowa Archiwum UMK, Arch. 722.

47 AUMK, Akta własne, Remonty obiektów budowlanych, sygn. 2001/24; Eksploatacja nieruchomości [m.in. sprawy dot. zalań], sygn. 2001/29; Finansowanie jednostek organizacyjnych. Realizacja budżetu [Korespondencja], t. 2, sygn. 2001/35.

48 Ustawa z dnia 8 października 2004 r. o włączeniu Akademii Medycznej im. Ludwika Rydygiera w Bydgoszczy do Uniwersytetu Mikotaja Kopernika w Toruniu, Dz.U. 2004, nr 241, poz. 2414. 
Medicum UMK w Bydgoszczy, a tamtejsze archiwum zakładowe weszło w skład systemu archiwalnego uniwersytetu ${ }^{49}$.

Stale rosnący zasób spowodował, że dr Moraczewska wielokrotnie podejmowała próby pozyskania nowych magazynów. 31 grudnia 2007 r. zasób archiwum liczył 200023 j.a., 43 spuścizny, 4117 pozytywów, 1209 negatywów, 200 nagrań dźwiękowych, 250 nagrań audio-wideo i kontynuowane wycinki prasowe. Całość liczyła około $3000 \mathrm{mb}$. akt ${ }^{50}$. Władze uczelni w styczniu 2008 r. przekazały jednostce dodatkowe magazyny w miejscu dawnej Stołówki Akademickiej nr 1, która mieściła się w Domu Studenckim nr 1 przy ul. Mickiewicza 2/4; ich powierzchnia wynosiła $370 \mathrm{~m}^{2} 51$. Tam też zostały przeniesione pomieszczenia biurowe i pracownia naukowa. Dodatkowo archiwum zyskało salę konferencyjno-dydaktyczną, gdzie do marca 2015 r. prowadzone były zajęcia ze studentami archiwistyki i zarządzania dokumentacją. Z uwagi na organizowane $\mathrm{w}$ archiwum praktyki studenckie, obecnie sala została przystosowana do zajęć praktycznych. Całkowita powierzchnia nowych pomieszczeń wynosi $710 \mathrm{~m}^{2}$.

Obowiązki kierownika po dr Moraczewskiej przez niespełna rok pełnił prof. Janusz Tandecki ${ }^{52}$. Od października 2011 r. kierownikiem Archiwum UMK jest dr hab. Anna Supruniuk ${ }^{53}$.

Obecnie (stan na 31 grudnia 2016 r.) archiwum dysponuje: 314021 j.a.; w tym 785 j.a. depozytów; 66 spuściznami; 6342 nagraniami na taśmach magnetofonowych oraz nośnikach cyfrowych z lat 1965-2016; 7978 pozytywami i 19244 negatywami z lat 1945-2016, nie wliczając jednostek fotograficznych pochodzących ze spuścizn; 640 filmami wideo, na kasetach VHS, płytach CD i DVD oraz dysku zewnętrznym $z$ lat 1960-2016; a także wycinkami prasowymi z lat 1945-2016. Łącznie zasób liczył 4523,24 mb. akt ${ }^{54}$. Akta przechowywane są $w$ czterech magazynach. Pierwsze trzy magazyny mieszczą się w piwnicy przy ul. Gagarina 13a, czwarty przy ul. Mickiewicza. W magazynie pierwszym znajdowały się regały tradycyjne, na których umieszczone były akta byłego już Wydziału Biologii i Nauk o Ziemi, Wydziału Matematyki Fizyki i Chemii oraz Wydziału Nauk Ekonomicznych i Zarządzania, a także akta komórek i jednostek, np. Działu Nauki i Studium Praktycznej Nauki

${ }^{49}$ AUMK, Akta własne, Organizacja jednostki działalności ogólnouczelnianej. Collegium Medicum [także sprawy z działalności], t. 1, znak sprawy: Arch. 0131-2/06; zob. też: I. Makacewicz, Historia Archiwum Zaktadowego Collegium Medicum w Bydgoszczy, [w:] Jubileusz 60-lecia Archiwum Uniwersytetu Mikotaja Kopernika w Toruniu, s. 47-53.

${ }^{50}$ H. Duczkowska-Moraczewska, B. Kierzkowska, dz. cyt., s. 32-34, 37.

51 AUMK, Akta własne, Posiedzenia Rady Archiwum UMK, znak sprawy: Arch. 0031$-1 / 07$

${ }^{52}$ AUMK, Sprawy osobowe pracowników Archiwum UMK, znak akt: Arch. 120.

53 Tamże.

54 AUMK, Akta własne, Plany i sprawozdania. Archiwum UMK, znak akt: Arch. 0331. 
Języków Obcych. W 2015 r. wymieniono tradycyjne regały na kompaktowe, zyskując tym samym dodatkowe metry (całość 579 mb.). Na nowe regały przeniesiono zespoły zamknięte, m.in. Studencką Agencję Radiową, Studium Wojskowe, Towarzystwo Miłośników Wilna i Ziemi Wileńskiej, Rolniczy Zakład Doświadczalny etc. We wnętrzu ustawiono jedno stanowisko pracy. Okno w tym pomieszczeniu wychodzi na atrium Wydziału Nauk Pedagogicznych. Z uwagi na duże nasłonecznienie zostało przysłonięte roletą wewnętrzną. Magazyn drugi zajmuje największą powierzchnię. W nim znajdują się regały przesuwne typu kompakt (3097,5 mb.), a także trzy stanowiska do pracy. Ostatnio zamontowano tutaj komputer stacjonarny. Zasób zgromadzony w tym magazynie to głównie akta studenckie (do sygnatury 151 999) i akta kadrowe, ale także akta Wydziału Prawa i Administracji oraz kilku komórek administracyjnych, np. Działu Współpracy z Zagranicą, Działu Rekrutacji i Spraw Studenckich, Działu Kształcenia. Okna zabezpieczone są stalowymi kratami, a w 2015 r. zamontowano wewnętrzne rolety, które ograniczają dostęp nadmiaru światła do pomieszczenia. Magazyny pierwszy i drugi posiadają wysokie progi zabezpieczające przed dostaniem się wody do wewnątrz. W trzecim magazynie do września 2016 r. znajdowały się regały tradycyjne, o łącznej długości 295,50 mb. Po wymianie na nowe regały przesuwne typu Compactus Officedo, zyskano dodatkową, ponad dwukrotnie większą powierzchnię magazynową (całość 706,8 mb.). Pomieszczenie to posiada wentylacje $\mathrm{w}$ postaci kratek nawiewowych oraz dwa stanowiska pracy. W tym magazynie znajdują się materiały po uczonych $^{55}$ oraz akta Wydziału Humanistycznego, Wydziału Chemii, Wydziału Matematyki i Informatyki, Wydziału Filologicznego oraz Wydziału Sztuk Pięknych. Poza tymi trzema magazynami, zagospodarowano także przestrzeń na długim korytarzu; łączna długość półek na regałach tradycyjnych wynosi 44 mb., znajdują się na nich akta Działu Płac. Magazyn czwarty, usytuowany w miejscu dawnej Stołówki Akademickiej nr 1 posiada regały kompaktowe. Obecnie łączny metraż na nich wynosi 3038,40 mb. W tym magazynie znajdują się akta studenckie powyżej sygnatury 152000 oraz akta Wydziału Nauk Pedagogicznych, Wydziału Teologicznego, Wydziału Nauk Historycznych, kilka mniejszych zespołów pochodzących z komórek i jednostek organizacyjnych UMK. Pomieszczenie posiada okratowane okna, w których zainstalowano rolety wewnętrzne, oraz stanowisko do pracy. Niestety, zmienna temperatura nie wpływa pozytywnie na dokumentację $\mathrm{w}$ nim przechowywaną. $W$ okresie jesienno-zimowym $\mathrm{w}$ tym magazynie panuje niska temperatura powietrza, natomiast w okresie letnim wysoka, która powoduje duszność oraz wysoką wilgotność. Od 2013 r. Archiwum UMK dysponu-

55 Alfabetyczny spis spuścizn i depozytów dostępny jest na stronie internetowej Archiwum UMK http:/ / www.archiwum.umk.pl/zasob/charakterystyka/ (dostęp 3 listopada 2017). 
je półprofesjonalnymi osuszaczami powietrza, dzięki którym poziom wilgotności obniżony zostaje do 45-50\%. Do magazynu przynależy pomieszczenie, w którym przechowywane się materiały ulotne, nagrania audiowizualne, dokumentacja elektroniczna i fotograficzna.

Podsumowując ponad 65 lat działalności jednostki, warto wymienić wszystkich byłych i obecnych pracowników archiwum, zaznaczając, że obecnie zatrudnionych jest sześć osób: pięć na stanowiskach merytorycznych oraz jednana stanowisku pomocniczym (tabela 1. $)^{56}$.

Tabela 1. Wykaz pracowników Archiwum Uniwersytetu Mikołaja Kopernika w Toruniu ${ }^{57}$

\begin{tabular}{|c|c|c|}
\hline Pracownik & Lata zatrudnienia & Stanowisko* \\
\hline prof. Bronisław Włodarski & 16 IX 1948 - IV 1951 & kierownik \\
\hline mgr Tadeusz Grudziński & 1 X 1949 - 31 VIII 1951 & archiwista \\
\hline doc. Leonid Żytkowicz & IV 581951 - 31 VIII 1954 & kierownik \\
\hline dr Józef Mossakowski & 15 IX 1954 - 31 XII 1965 & kierownik \\
\hline doc. Irena Janosz- Biskupowa & 1 I 1966 - 30 IX ${ }^{59} 1976$ & kierownik \\
\hline $\begin{array}{l}\text { dr Henryka Duczkowska-- } \\
\text { Moraczewska }\end{array}$ & 1 X 1969 - 31 XII 2010 & $\begin{array}{l}\text { kierownik, starszy dokumen- } \\
\text { talista dyplomowany }\end{array}$ \\
\hline Teresa Kałkus-Stemplewska & 7 I 1970 - IX 1977 & archiwista \\
\hline mgr Renata Karpiesiuk & 15 I 1974 - 30 VI 2012 & starszy dokumentalista \\
\hline Ewa Wiśniewska & 15 IX 1977 - 31 X 2015 & samodzielny referent \\
\hline Elżbieta Talarczyk & 1 I 1979 - 30 IV 2009 & samodzielny referent \\
\hline mgr Katarzyna Namysłowska & 1 IX 1985 - 29 VIII 1988 & archiwista \\
\hline Grażyna Gnich & 12 III 1986 - 29 XI 2017 & starsza woźna \\
\hline Grażyna Cholewczuk & 1 XII 1988 - 30 IX 1989 & technik \\
\hline mgr Beata Herdzin & 1 X 1991 - 30 VI 1992 & młodszy dokumentalista \\
\hline mgr Jan Wiśniewski & 15 XI 1999 - 31 VIII 2000 & młodszy dokumentalista \\
\hline
\end{tabular}

56 Pierwowzorem jest tabela zamieszczona w: H. Duczkowska-Moraczewska, B. Kierzkowska, dz. cyt., s. 29-30. Niniejsza tabela została poprawiona i uzupełniona. Wykaz pracowników Archiwum UMK nie zawiera osób zatrudnionych na umowy zlecenie oraz zastępstwo.

57 AUMK, Akta własne, Angażowanie i zwalnianie pracowników [przeniesienia, zastępstwo, itp.], sygn. 2001/69; Organizacja UMK, sygn. 2002/1.

* Informacja zawarta w tej kolumnie, odnosi się do ostatnio zajmowanego stanowiska.

$58 \mathrm{~W}$ aktach pracowniczych archiwum, a także w dostępnej literaturze funkcjonuje data zatrudnienia 28 VIII 1951 r., ale w aktach osobowych Żytkowicza, w zaświadczeniu Dyrektora Administracyjnego UMK z 11 czerwca 1953 r., L. 3198/53, czytamy, że L. Żytkowicz „od kwietnia 1951 r. pełni obowiązki pracownika naukowego archiwum UMK", AUMK, Akta własne, Akta osobowe pracowników Archiwum UMK [także pracownicy na umowę zlecenie i umowę o dzieło], sygn. 2001/21; AUMK, Akta osobowe L. Żytkowicza, sygn. K-9/430.

59 AUMK, Akta osobowe I. Janosz-Biskupowej, sygn. K-24/74. 


\begin{tabular}{|l|l|l|}
\hline \multicolumn{1}{|c|}{ Pracownik } & \multicolumn{1}{|c|}{ Lata zatrudnienia } & \multicolumn{1}{c|}{ Stanowisko } \\
\hline mgr Bożena Kierzkowska & 1 VIII 2000 - do dziś & starszy dokumentalista \\
mgr Jolanta Malicka & 1 V 2009 - 18 XII 2010 & młodszy dokumentalista \\
dr Paulina Bunkowska & 1 V 2009 - do dziś & starszy dokumentalista \\
Teresa Gałka & 1 VIII 2009 - do dziś & porządkowa \\
prof. Janusz Tandecki & 1 I 2011 - 30 IX 2011 & p.o. kierownika \\
mgr Weronika Krajniak & 1 VII 2011 - do dziśs & dokumentalista \\
dr hab. Anna Supruniuk & 1 X 2011 - do dziś & kierownik, starszy kustosz \\
& 1yplomowany \\
mgr Jacek Waliszewski & III 2012 - do dziś & dokumentalista \\
mgr Magda Banna & 1 I 2016 - 23 X 2017 & młodszy dokumentalista \\
\hline
\end{tabular}

Weronika Krajniak

\section{Rys historyczny Archiwum Uniwersytetu Mikołaja Kopernika w Toruniu}

\section{Streszczenie}

Artykuł zatytułowany Rys historyczny Archiwum UMK w Toruniu porządkuje i uzupełnia dotychczasowe informacje podane we wcześniejszej literaturze dotyczące archiwum. Został oparty nie tylko na istniejących już publikacjach, ale przede wszystkim na materiałach źródłowych. Punktem wyjścia była uchwała Senatu UMK z 16 września 1948 roku powołująca archiwum i powierzająca jego organizację prof. Bronisławowi Włodarskiemu. Następnie Autorka podaje informacje dotyczące zasobu archiwalnego, miejsc przechowywania za poszczególnych kierowników, a także zmian zachodzących w organizacji pracy archiwum. W podsumowaniu została zamieszczona tabela z wykazem wszystkich pracowników od początków istnienia archiwum.

Słowa kluczowe: Archiwum UMK, Uniwersytet Mikołaja Kopernika, Toruń, zasób archiwalny, archiwoznawstwo, materiały archiwalne, rys historyczny

\section{The history of the Nicolaus Copernicus University archive in Toruń}

\footnotetext{
Abstract

The article organizes and complements the existing literature information concerning the archive of the Nicolaus Copernicus University in Torun. It is based not only on the existing publications, but mainly on source materials. The starting point was the resolution of the Nicolaus Copernicus University Senate of September 16, 1948, establishing the archive and trusting pro-
} 
fessor Bronisław Włodarski with the implementation of this task. The next section is dedicated to archival fonds, their locations during subsequent heads' terms of office, as well as transformations in the organization of the archive's work. The conclusion includes a table listing all employees of the archive since its establishment.

Keywords: Nicolaus Copernicus University Archive, Nicolaus Copernicus University, Torun, archival fonds, archival science, archive materials, history 